\title{
The Number of Cells and the Rate of Cell Division in Parthenogenetic and Fertilized Mouse Embryos during the Course of Blastocyst Formation
}

\author{
Sueo Niimura ${ }^{1 *}$, Yukino Nakamura ${ }^{2}$ and Kota Yoshino ${ }^{2}$ \\ ${ }^{1}$ Faculty of Agriculture and \\ ${ }^{2}$ Graduate School of Science and Technology, Niigata University, Niigata 950-2181, Japan
}

\begin{abstract}
The number of cells and the rate of cell division were observed in diploid parthenogenetic mouse embryos during the course of blastocyst formation, and were compared with those in embryos developed from fertilized ova (fertilized embryos), in order to identify the stage at which the number of cells begins to differ and the cause of difference in cell number between parthenogenetic and fertilized embryos. The number of cells and the rate of cell division did not differ between parthenogenetic and fertilized embryos at the 8-cell and compacted morula stages. The numbers of inner-cell-mass and trophoblast cells did not differ between parthenogenetic and fertilized embryos at the early blastocyst stage, but were significantly fewer in parthenogenetic embryos (11.1 and 32.7) than in fertilized embryos (14.9 and 52.0) at the expanded blastocyst stage. The numbers of dead innercell-mass and trophoblast cells were significantly more in parthenogenetic embryos than in fertilized ones at the early and expanded blastocyst stages. At the early blastocyst stage, although no difference was observed between parthenogenetic and fertilized embryos in the rate of division of trophoblast cells, the rate of division of inner-cell-mass cells was significantly lower in parthenogenetic embryos (4.4\%) than in fertilized ones $(9.7 \%)$. There was no difference in the rate of cell division between parthenogenetic and fertilized embryos at the expanded blastocyst stage. From these results, it was inferred that the number of cells in diploid parthenogenetic embryos does not differ from fertilized embryos until blastocyst formation, but becomes fewer than in fertilized embryos because more cells are dying
\end{abstract}

Received: March 26, 2002

Accepted: May 7, 2002

*To whom correspondence should be addressed.

e-mail: niimura@agr.niigata-u.ac.jp in parthenogenetic embryos during the expansion of blastocysts. A low rate of cell division in the early blastocyst stage is thought to be one reason for the fewer number of inner-cell-mass cells in parthenogenetic embryos at the expanded stage, in addition to the presence of a large number of dead cells. Key words: Mouse, Parthenogenetic embryo, Blastocyst formation, Cell number, Rate of cell division

Parthenogenesis is the phenomenon in which an ovum begins to develop by activation without sperm penetration. Artificial induction of this phenomenon is thought to be useful in clarifying the mechanisms of ovum activation and to investigate the role of sperm in embryo development [1]. Although parthenogenetic embryos are prepared in mammals by various methods, all attempts to obtain newborns from such embryos have failed [2, 3]. Furthermore, parthenogenetic embryos are also known to have a low potential of development in vitro [4, 5]. Slower cell division $[1,5]$, low metabolic activities [6-11], ultrastructural disorders $[1,6,12-14]$, the lack of imprinting of paternal genomes [15-17] and high frequencies of chromosomal anomalies $[4,6,18,19]$ have been reported as explaining the low developmental potency of parthenogenetic embryos and the failure to obtain newborns.

On the other hand, it has been reported that the number of cells in parthenogenetic embryos is fewer than that in embryos developed from fertilized ova (fertilized embryos) [1, 2, 5, 6, 20, 21]. Namely, parthenogenetic blastocysts developed from ova activated and diploidized by treatment with ethanol and cytochalasin $B$ or $D$ had a significantly smaller number of cells, 32.1 [6], 35.2 [1], 52.9 [20] and 69.4 [21] on 
average, compared with fertilized blastocysts, which respectively had 47.2 [6], 51.9 [1], 66.1 [20] and 86.6 [21] cells on average in the same stage. It has also been said that diploid parthenogenetic mouse blastocysts have about 20 inner-cell-mass cells [5] or about half of those observed in blastocysts developed from fertilized ova [2]. This smaller cell number in parthenogenetic blastocysts is thought to be related to the high mortality of these embryos after implantation $[1,2,5,6,20,21]$. As mentioned above, comparison of cell numbers between parthenogenetic and fertilized embryos has been performed only at the blastocyst stage and it is unclear which stage of development accounts for the difference.

In the present study, the number of cells in diploid parthenogenetic mouse embryos was examined and compared with that of fertilized embryos during the course of blastocyst formation, in order to identify the stage at which the number of cells began to differ between parthenogenetic and fertilized embryos. Furthermore, the numbers of dead cells and the rates of cell division were observed in both parthenogenetic and fertilized embryos during the course of blastocyst formation, in order to clarify the cause of difference in cell number between parthenogenetic and fertilized embryos.

\section{Materials and Methods}

\section{Animals}

Two hundred and eighty mature female mice of the ICR strain prepared by mating at our laboratory were used in the present study. They were housed in autoclaved metal cages and were given a standard diet (MF, Oriental Yeast Co., Tokyo, Japan) and tap water ad libitum in an air-conditioned room $\left(24^{\circ} \mathrm{C}\right)$, under controlled-lighting conditions (14L/10D; L: 4:00 a.m. to 6:00 p.m.). These females were intraperitoneally injected with 5 i.u. of PMSG (Serotropin ${ }^{\circledR}$, Teikoku Hormone Manufacturing Co. Ltd., Tokyo, Japan), and with 5 i.u. of hCG (Gonatropin ${ }^{\circledR}$, Teikoku Hormone Manufacturing Co. Ltd.) 48 hrs later to induce superovulation. About one third of superovulated female mice were mated with mature males of the same strain.

\section{Preparation of embryos}

To induce parthenogenesis, unfertilized ova were recovered from superovulated females $14 \mathrm{hrs}$ after the hCG injection and were immersed in M2 medium [22] containing $100 \mu \mathrm{M}$ EDTA-2Na (EDTA-M2 medium) and
$7 \%$ ethanol for $7 \mathrm{~min}$ at room temperature, and then in EDTA-M2 medium containing cytochalasin B (Sigma Chemical Co., MO, USA) at $5 \mu \mathrm{g} / \mathrm{ml}$ for $6 \mathrm{hrs}$ at $37^{\circ} \mathrm{C}$. The treated ova were immersed in EDTA-M2 medium containing $0.1 \%$ hyaluronidase (Sigma Chemical Co.) to remove the cumulus cells, and were then cultured in EDTA-M2 medium for $22 \mathrm{hrs}$ in a $\mathrm{CO}_{2}$ incubator $(5 \%$ $\mathrm{CO}_{2}$ in air) at $37^{\circ} \mathrm{C}$. After being rinsed 3 times with $\mathrm{M} 16$ medium [23], 2-cell embryos developed from the treated ova were further cultured in M16 medium. As controls, sperm-penetrated ova were collected from superovulated and mated females $14 \mathrm{hrs}$ after the hCG injection, and cultured in EDTA-M2 medium for $28 \mathrm{hrs}$ and then successively cultured in M16 medium.

The parthenogenetic and fertilized embryos observed were 8-cell embryos composed of only round blastomeres, compacted morulae, early blastocysts and expanded blastocysts measuring 80 to $100 \mu \mathrm{m}$ in diameter.

\section{Observation of cell number and frequency of mitosis}

In order to investigate the number of cells, parthenogenetic and fertilized embryos at the stages of compacted morula, early blastocyst and expanded blastocyst were treated with the method used by Handyside and Hunter [24]. These embryos were immersed in acidic Tyrode solution ( $\mathrm{pH} 2.5)$ [25] to dissolve their zonae pellucidae. After rinsing in M16 medium, the naked embryos were immersed for $3 \mathrm{~min}$ at room temperature in rabbit anti-mouse splenocyte antiserum diluted 5 times with M16 medium. The embryos treated with the antiserum were rinsed in M16 medium, and immersed in guinea pig complement serum (Gibco BRL, NY, USA) containing $0.01 \%$ propidium iodide (Sigma Chemical Co.) for $5 \mathrm{~min}$ at $37^{\circ} \mathrm{C}$, this complement being diluted 10 times with $\mathrm{M} 16$ medium. Then, the treated embryos were fixed and stained in ethanol containing $0.5 \mathrm{mM}$ Hoechst 33342 (Molecular Probe, OR, USA) for $3 \mathrm{~min}$ at $4^{\circ} \mathrm{C}$.

Parthenogenetic and fertilized embryos at the untransformed 8-cell, compacted morula, early blastocyst and expanded blastocyst stages were incubated in M16 medium containing vinblastine (Sigma Chemical Co.) at $30 \mathrm{ng} / \mathrm{ml}$ for $4 \mathrm{hrs}$ at $37^{\circ} \mathrm{C}$, to observe the metaphase plate. The embryos incubated with vinblastine were washed 3 times in M16 medium, and then treated by the method [24] mentioned above.

Each of the embryos prepared for the observation of cell number or cell division was placed on a glass slide for photography under a reflected-light fluorescence microscope (Nikon Corporation, Tokyo, Japan). The 

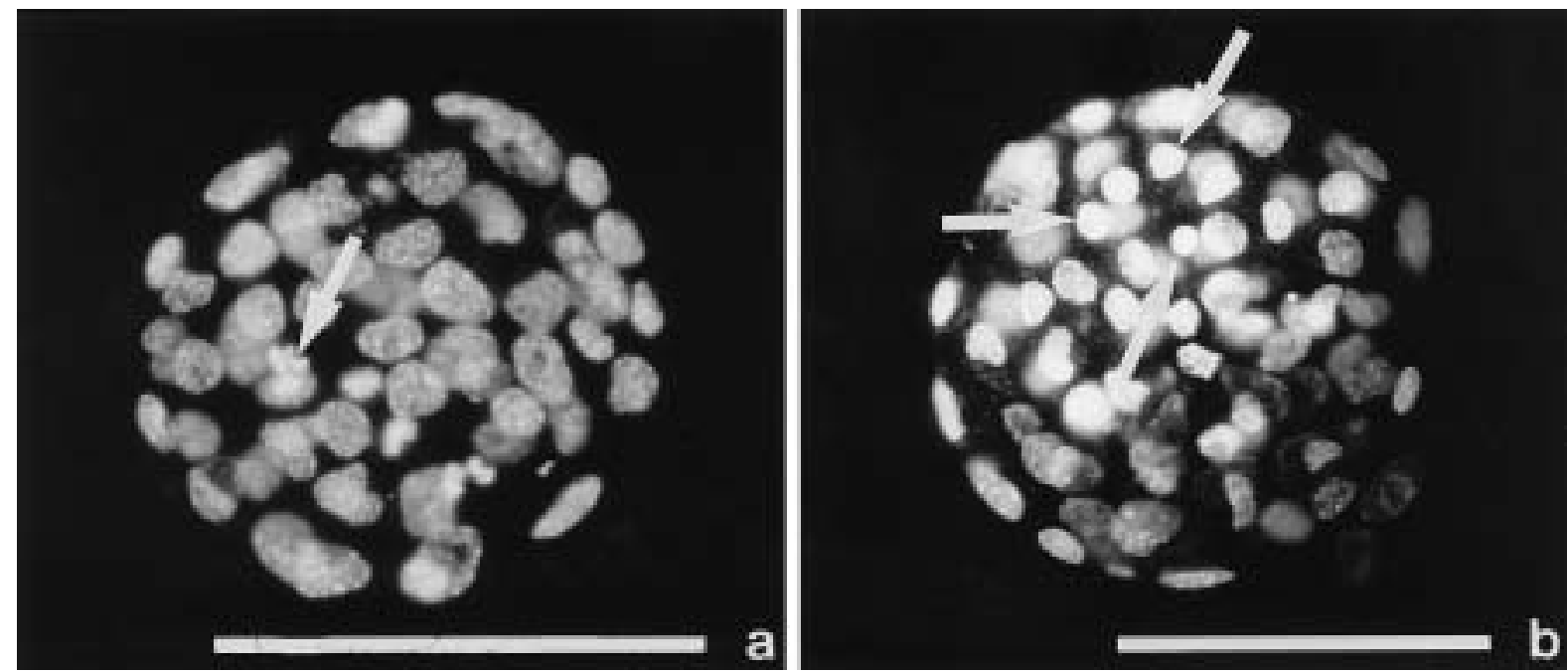

Fig. 1. Fluorescence micrographs of parthenogenetic (a) and fertilized (b) mouse expanded blastocysts taken after staining with the method of Handyside and Hunter. Scales indicate $100 \mu \mathrm{m}$. a. A nucleus (arrow) of dead inner-cell-mass cell. b. Nuclei (arrows) of trophoblast cells at the metaphase stage of mitosis.

same procedures of observation were repeated 3 times, using 30 embryos in all for every developmental stage. Living cells and dead cells were identified according to morphological features used by Hardy and Handyside [21]. Namely, nuclei of living cells had a distinct nuclear outline and brightly stained nucleoli, while those of dead cells did not maintain the morphology as living cells, resulting in fragmentation. On the other hand, cells with condensed chromosomes (metaphase plates) were judged to be at the metaphase stage of mitosis. The frequency of division in each blastomere, trophoblast cell or inner-cell mass cell was calculated as follows:

Number of cells with metaphase plates Total number of cells

\section{Statistical analysis}

Statistical analysis of the cell number was performed by one-way analysis of variance. The frequency of cell division was also statistically analyzed using one-way analysis of variance after angular transformation.

\section{Results}

When parthenogenetic and fertilized embryos during the course of blastocyst formation were observed under a fluorescence microscope after being treated by the method of Handyside and Hunter [24], nuclei were stained pink in round blastomeres of 8-cell embryos, flattened blastomeres of morulae and trophoblast cells of blastocysts, and stained blue in round blastomeres of morulae and inner-cell-mass cells of blastocysts (Fig. $1 \mathrm{a}, \mathrm{b})$. Nuclei of living cells were spherical or oval in blastomeres and cells of all embryos, while those of dead cells were also stained equally to those of living cells, none of the nuclei maintained the morphology described above (Fig. 1a). Further, nuclei in the metaphase stage of mitosis had no nuclear envelope in embryos at any stage, and they appeared irregular in shape and condensed (Fig. 1b).

\section{Cell number}

As shown in Table 1, there were no differences in the number of round and flattened blastomeres between parthenogenetic and fertilized embryos at the compacted morula stage. Both parthenogenetic and fertilized morulae had no dead round blastomeres. At the early blastocyst stage, although no differences were observed between parthenogenetic and fertilized embryos in the number of inner-cell-mass and trophoblast cells, the number of dead inner-cell-mass and trophoblast cells was significantly more in parthenogenetic embryos than in fertilized ones. The number of inner-cell-mass and trophoblast cells was fewer in parthenogenetic embryos than in fertilized ones at the expanded blastocyst stage, while that of dead inner-cell-mass and trophoblast cells was more in parthenogenetic embryos than in fertilized ones.

\section{Cell division}

There were no differences in the rate of division of 
Table 1. The number of cells in mouse embryos during the course of blastocyst formation

\begin{tabular}{|c|c|c|c|c|c|c|c|c|c|}
\hline \multirow[b]{2}{*}{ Embryos } & \multicolumn{3}{|c|}{ Compacted morula } & \multicolumn{3}{|c|}{ Early blastocyst } & \multicolumn{3}{|c|}{ Expanded blastocyst } \\
\hline & $\begin{array}{c}\text { No. of } \\
\text { round } \\
\text { blastomeres }\end{array}$ & $\begin{array}{c}\text { No. of } \\
\text { flattened } \\
\text { blastomeres }\end{array}$ & Total & $\begin{array}{l}\text { No. of } \\
\text { inner-cell- } \\
\text { mass cells }\end{array}$ & $\begin{array}{l}\text { No. of } \\
\text { trophoblast } \\
\text { cells }\end{array}$ & Total & $\begin{array}{c}\text { No. of } \\
\text { inner-cell- } \\
\text { mass cells }\end{array}$ & $\begin{array}{c}\text { No. of } \\
\text { trophoblast } \\
\text { cells }\end{array}$ & Total \\
\hline \multicolumn{10}{|c|}{ Parthenogenone } \\
\hline & $\begin{array}{r}6.7 \pm 0.40^{\# \mathrm{a}} \\
\left(0.0 \pm 0.00^{\mathrm{a}}\right)\end{array}$ & $\begin{array}{c}11.3 \pm 0.52^{\mathrm{a}} \\
\left(0.1 \pm 0.12^{\mathrm{a}}\right)\end{array}$ & $\begin{array}{c}17.9 \pm 0.74^{\mathrm{a}} \\
\left(0.1 \pm 0.12^{\mathrm{a}}\right)\end{array}$ & $\begin{array}{c}7.9 \pm 0.38^{\mathrm{a}} \\
\left(0.4 \pm 0.15^{\mathrm{a}}\right)\end{array}$ & $\begin{array}{c}14.3 \pm 0.73^{\mathrm{a}} \\
\left(0.7 \pm 0.17^{\mathrm{a}}\right)\end{array}$ & $\begin{array}{c}22.2 \pm 0.98^{\mathrm{a}} \\
\left(1.1 \pm 0.27^{\mathrm{a}}\right)\end{array}$ & $\begin{array}{l}11.1 \pm 0.52^{\mathrm{b}} \\
\left(0.9 \pm 0.23^{\mathrm{a}}\right)\end{array}$ & $\begin{array}{c}32.7 \pm 1.86^{\mathrm{b}} \\
\left(1.2 \pm 0.24^{\mathrm{a}}\right)\end{array}$ & $\begin{array}{l}43.8 \pm 1.96^{\mathrm{b}} \\
\left(2.1 \pm 0.33^{\mathrm{a}}\right)\end{array}$ \\
\hline \multicolumn{10}{|l|}{ Fertilized } \\
\hline & $\begin{array}{c}6.3 \pm 0.39^{\mathrm{a}} \\
\left(0.0 \pm 0.00^{\mathrm{a}}\right)\end{array}$ & $\begin{array}{c}11.2 \pm 0.52^{\mathrm{a}} \\
\left(0.2 \pm 0.11^{\mathrm{a}}\right)\end{array}$ & $\begin{array}{c}17.5 \pm 0.66^{\mathrm{a}} \\
\left(0.2 \pm 0.11^{\mathrm{a}}\right)\end{array}$ & $\begin{array}{c}8.1 \pm 0.37^{\mathrm{a}} \\
\left(0.0 \pm 0.00^{\mathrm{b}}\right)\end{array}$ & $\begin{array}{c}14.8 \pm 0.77^{\mathrm{a}} \\
\left(0.2 \pm 0.17^{\mathrm{b}}\right)\end{array}$ & $\begin{array}{c}23.0 \pm 0.96^{\mathrm{a}} \\
\left(0.2 \pm 0.17^{\mathrm{b}}\right)\end{array}$ & $\begin{array}{l}14.9 \pm 0.52^{\mathrm{a}} \\
\left(0.3 \pm 0.15^{\mathrm{b}}\right)\end{array}$ & $\begin{array}{l}52.0 \pm 2.29^{\mathrm{a}} \\
\left(0.6 \pm 0.17^{\mathrm{b}}\right)\end{array}$ & $\begin{array}{c}66.9 \pm 1.69^{\mathrm{a}} \\
\left(0.9 \pm 0.21^{\mathrm{b}}\right)\end{array}$ \\
\hline
\end{tabular}

\#Mean \pm S.E. Values of the upper section and values in parentheses each represent the total number of living cells and dead cells and the number of dead cells, respectively; those with different superscripts in the same column are significantly different $(\mathrm{P}<0.05)$.

Table 2. The rate of cell division in mouse embryos during the course of blastocyst formation

\begin{tabular}{|c|c|c|c|c|c|c|c|}
\hline \multirow[b]{2}{*}{ Embryos } & \multirow{2}{*}{$\begin{array}{c}\text { 8-Cell } \\
\text { Round } \\
\text { blastomeres }\end{array}$} & \multicolumn{2}{|c|}{ Compacted morula } & \multicolumn{2}{|c|}{ Early blastocyst } & \multicolumn{2}{|c|}{ Expanded blastocyst } \\
\hline & & $\begin{array}{c}\text { Round } \\
\text { blastomeres }\end{array}$ & $\begin{array}{c}\text { Flattened } \\
\text { blastomeres }\end{array}$ & $\begin{array}{l}\text { Inner-cell- } \\
\text { mass cells }\end{array}$ & $\begin{array}{l}\text { Trophoblast } \\
\text { cells }\end{array}$ & $\begin{array}{l}\text { Inner-cell- } \\
\text { mass cells }\end{array}$ & $\begin{array}{l}\text { Trophoblast } \\
\text { cells }\end{array}$ \\
\hline Parthenog & $6.9 \pm 1.68^{\mathrm{\# a}}$ & $4.4 \pm 1.52^{\mathrm{a}}$ & $5.1 \pm 1.29^{\mathrm{a}}$ & $4.4 \pm 1.38^{b}$ & $5.3 \pm 1.43^{\mathrm{a}}$ & $8.0 \pm 1.93^{\mathrm{a}}$ & $3.2 \pm 0.79^{\mathrm{a}}$ \\
\hline Fertilized & $7.7 \pm 1.69^{\mathrm{a}}$ & $5.0 \pm 1.83^{\mathrm{a}}$ & $6.4 \pm 1.92^{\mathrm{a}}$ & $9.7 \pm 2.08^{\mathrm{a}}$ & $6.0 \pm 1.61^{\mathrm{a}}$ & $7.4 \pm 1.88^{\mathrm{a}}$ & $4.1 \pm 1.64^{\mathrm{a}}$ \\
\hline
\end{tabular}

${ }^{\#}$ Mean \pm S.E. (\%). Values with different superscripts in the same column are significantly different $(\mathrm{P}<0.05)$.

round and flattened blastomeres between parthenogenetic and fertilized embryos at the 8-cell and morula stages (Table 2). At the early blastocyst stage, the rate of division in trophoblast cells did not differ between parthenogenetic and fertilized embryos, but a significantly lower rate of division in inner-cell-mass cells was observed in parthenogenetic embryos, compared with that in fertilized embryos. No significant differences were observed in the rate of division of inner-cell-mass and trophoblast cells between parthenogenetic and fertilized embryos at the expanded blastocyst stage.

\section{Discussion}

A small number of cells at the blastocyst stage is considered to be a cause of low developmental potency in parthenogenetic embryos [1, 2, 5, 6, 20, 21], although it was unclear when the difference in cell number appeared between parthenogenetic and fertilized embryos during the course of blastocyst formation.

The present study revealed for the first time that the number of cells at the morula stage did not differ between diploid parthenogenetic and fertilized embryos. The number of cells at the early blastocyst stage also did not differ between parthenogenetic and fertilized embryos, but parthenogenetic embryos at the expanded blastocyst stage were found to have significantly fewer cells, both trophoblast and inner-cell-mass cells, compared with fertilized embryos. Thus it may be said that the number of cells in diploid parthenogenetic mouse embryos is equal to that in fertilized embryos until the blastocyst formation, but becomes different from that of fertilized embryos during the expansion of blastocysts.

The rate of cell division determined by the $4 \mathrm{hrs}$ treatment with vinblastine did not differ between parthenogenetic and fertilized embryos at the 8-cell, morula and expanded blastocyst stages (Table 2). The rate of division in trophoblast cells of parthenogenetic blastocysts was also found not to differ from that in fertilized embryos at the early stage, while the rate of division in inner-cell-mass cells was significantly lower in parthenogenetic embryos than in fertilized embryos. As for the number of dead cells, no difference was observed between parthenogenetic and fertilized embryos at the morula stage. On the other hand, it was confirmed in the present study that both dead trophoblast and inner-cell-mass cells were significantly more in parthenogenetic blastocysts at the early and expanded stages, compared with fertilized blastocysts. Hardy and Handyside [21] reported that dead 
trophoblast and inner-cell-mass cells in parthenogenetic blastocysts did not differ in number from those in fertilized blastocysts at the early stage, but were significantly more in parthenogenetic blastocysts at the expanded stage, compared with fertilized blastocysts. Thus, there is a discrepancy in the number of dead cells at the early blastocyst stage between their results [21] and ours. Although the reason for this discrepancy remains obscure, it may be attributable to a difference in age of the early blastocysts (98 hrs: Hardy and Handyside [21] vs. 104 hrs after hCG injection: the present study) used for observation. Thus, we assumed that the discrepancy occurred because blastocysts used in the present study were about 6 hrs older than those used by Hardy and Handyside [21].

The results of the present study suggest that the number of cells in diploid parthenogenetic expanded blastocysts becomes fewer than that in fertilized embryos because more cells are dying in parthenogenetic embryos during the expansion of blastocysts. A low rate of cell division at the early blastocyst stage is thought to be an additional reason for the fewer number of inner-cell-mass cells in parthenogenetic embryos at the expanded stage.

\section{References}

1) Whittingham, D.G. (1980): Parthenogenesis in mammals. In: Oxford Reviews of Reproductive Biology (Finn, C.A., ed.), 2nd ed., pp. 205-231, Clarendon Press, Oxford.

2) Thibault, C. (1949): The mammalian egg, its parthenogenetic development. Annls. Sci. Nat. Zool., 11, 133-219.

3) Chang, M.C. (1954): Development of parthenogenetic rabbit blastocysts induced by low temperature storage of unfertilized ova. J. Exp. Zool., 125, 127-149.

4) Kaufman, M.H. and Sachs, L. (1976): Complete preimplantation development in culture of parthenogenetic mouse embryos. J. Embryol. Exp. Morph., 35, 179-190.

5) Kaufman, M.H. (1981): Parthenogenesis is a system facilitating understanding of factors that influence early mammalian development. Prog. Anat., 1, 1-34.

6) Niimura, S. (1997): Morphological and histochemical characteristics of parthenogenetic embryos. J. Mamm. Ova Res., 14, 109-116.

7) Hansmann, I., Gebauer, J. and Grimm, T. (1978): Impaired gene activity for $18 \mathrm{~S}$ and $28 \mathrm{~S}$ rRNA in early embryonic development of mouse parthenogenones. Nature, 272, 377378.

8) Petzoldt, U. and Hoppe, P.C. (1980): Spontaneous parthenogenesis in Mus musculus: comparison of protein synthesis in parthenogenetic and normal preimplantation embryos. Molec. gen. Genet., 180, 547-552.
9) Ryan, J.P., Waite, K.M. and Catt, J.W. (1994): Metabolism of energy substrates following fertilization or parthenogenetic activation of mouse oocytes. Theriogenology, 41, 288.

10) Niimura, S. and Asami, T. (1997): Histochemical studies of enzymes in parthenogenetic mouse blastocysts. Jpn. J. Fertil. Steril., 42, 78-82.

11) Niimura, S. and Asami, T. (1997): A histochemical study of the steroid metabolism in parthenogenetic mouse blastocysts. J. Reprod. Dev., 43, 251-256.

12) Solter, D., Biczysko, W., Graham, C., Pienkowski, M. and Koprowski, H. (1974): Ultrastructure of early development of mouse parthenogenones. J. Exp. Zool., 188, 1-24.

13) Van Blerkom, J. and Runner, M.N. (1976): The fine structural development of preimplantation mouse parthenotes. J. Exp. Zool., 196, 113-124.

14) Niimura, S. and Asami, T. (1996): Ultrastructure of parthenogenetic mouse blastocysts. Jpn. J. Fertil. Steril., 41, 186-190.

15) McGrath, J. and Solter, D. (1984): Completion of mouse embryogenesis requires both the maternal and paternal genomes. Cell, 37, 179-183.

16) Surani, M.A.H., Barton, S.C. and Norris, M.L. (1984): Development of reconstituted mouse eggs suggests imprinting of the genome during gametogenesis. Nature, $308,548-550$.

17) Kono, T., Obata, Y., Yoshimzu, T., Nakahara, T. and Carroll, J. (1996): Epigenetic modifications during oocyte growth correlates with extended parthenogenetic development in the mouse. Nature Genetics, 13, 91-94.

18) Kaufman, M.H. (1982): The chromosome complement of single pronuclear haploid mouse embryos following activation by ethanol treatment. J. Embryol. Exp. Morph., 71, 139-154.

19) O’Neil, G.T. and Kaufman, M.H. (1989): Cytogenetic analysis of ethanol-induced parthenogenesis. J. Exp. Zool., 249, 182-192.

20) Mognetti, B. and Sakkas, D. (1996): Defects in the allocation of cells to the inner cell mass and trophectoderm of parthenogenetic mouse blastocysts. Reprod. Fert. Dev., 8, 1193-1197.

21) Hardy, K. and Handyside, A. (1996): Metabolism and cell allocation during parthenogenetic preimplantation mouse development. Molec. Reprod. Dev., 43, 313-322.

22) Fulton, B.P. and Whittingham, D.G. (1978): Activation of mammalian oocytes by intracellular injection of calcium. Nature, 273, 149-151.

23) Whittingham, D.G. (1971): Culture of mouse ova. J. Reprod. Fert. Suppl., 14, 7-21.

24) Handyside, A.L. and Hunter, S. (1984): A rapid procedure for visualizing the inner cell mass and trophectoderm nuclei of mouse blastocysts in situ using polynucleotidespecific fluorochromes. J. Exp. Zool., 231, 429-434.

25) Hogan, B., Constantini, F. and Lacy, E. (1994): Manipulating the Mouse Embryo, 2nd ed., pp. 415-421, Cold Spring Harbor Laboratory Press, New York. 